\title{
Peran Dan Perkembangan Perkeretaapian Cirebon Barat Pada Masa Hindia Belanda
}

Yana Maulana Firdaus Dedeh Nur Hamidah

Fakultas Ushuluddin Adab dan Dakwah yanamaulanafirdauss@gmail.com dedeh.dn92@gmail.com

IAIN Syekh Nurjati Cirebon

\section{ABSTRACT}

The Dutch East Indies government in 1870 issued a liberal trade policy, whereby private capital began to enter the Dutch East Indies. The result of this policy is an influx of investment in the plantation industry sector, one of which is sugarcane. In line with that, a railroad land transportation was built which was originally to facilitate the distribution of industrial sugarcane products. In the Cirebon area itself, the construction of the railway line began in 1897, namely the construction of the Cirebon-Semarang line, then in 1901 the Cirebon-Kadipaten line was built, and in 1912 the Cirebon-Cikampek line was built. The role of the new routes in West Cirebon in the economic sector, among others, is to provide a smooth production process for the sugar factory in West Cirebon. In addition, the social role of the railway line in West Cirebon is to provide smoother access to mobility of goods between regions.

Keywords: Railway, West Cirebon, Economy, Social

\begin{abstract}
ABSTRAK
Pemerintah Hindia Belanda pada tahun 1870 mengeluarkan kebijakan perdagangan liberal, dimana modal-modal swasta mulai masuk ke Hindia Belanda. Hasil dari kebijakan tersebut adalah masuknya investasi di sektor industri perkebunan, salah satunya tebu. Sejalan dengan itu, dibangunlah transportasi darat kereta api yang pada mulanya untuk memfasilitasi distribusi produk industri tebu. Di wilayah Cirebon sendiri pembangunan
\end{abstract}


jalur kereta dimulai pada tahun 1897, yakni dengan dibangunnya jalur Cirebon-Semarang, kemudian tahun 1901 dibangun jalur CirebonKadipaten, serta tahun 1912 dibangun jalur Cirebon-Cikampek. Peran dari jalur-jalur baru di Cirebon Barat dalam sektor perekonomian antara lain adalah memberikan kelancaran proses produksi pabrik gula di wilayah Cirebon Barat. Selain itu, dalam peran sosial dari adanya jalur kereta di Cirebon Barat ini adalah memberikan akses mobilitas barang antar wilayah yang semakin lancar.

Kata Kunci: Kereta Api, Cirebon Barat, Ekonomi, Sosial

\section{PENDAHULUAN}

Transportasi mempunyai peranan yang sangat penting dalam pemenuhan kebutuhan manusia sehari-hari, salah satunya dalam sektor perekonomian, terutama yang berkaitan dengan masalah produksi, distribusi, dan konsumsi. Kebutuhan manusia yang saling membutuhkan satu dengan yang lainnya mengakibatkan munculnya daerah-daerah produksi atau sumber dari bahan baku kebutuhan manusia. Tujuan akhir proses ekonomi tersebut adalah konsumen. Dimana tempat para konsumen berkumpul disebut dengan pasar. Pasar pada umumnya merupakan daerah yang landai dan mempunyai akses tempat yang mudah untuk dijangkau. Indonesia sendiri terletak di antara lautan Hindia dan Pasifik serta benua Asia dan Australia, serta memiliki garis pantai dan hutan tropis yang tersebar hampir 3000 mil. ${ }^{1}$ Dengan keadaan alam yang seperti itu membuat Indonesia kaya akan sumber daya alam seperti rempahrempah dan lainnya, dan daerah garis pantai tersebut menjadi daerah

\footnotetext{
${ }^{1}$ Anwar Sanusi, Pengantar Ilmu Sejarah, (Cirebon: Syekh Nurjati Press. 2013), hlm 23. 359
}

Tamaddun: Jurnal Sejarah dan Kebudayaan Islam, Volume (8), Issue (2), Desember 2020 
potensial sebagai tempat berkumpulnya orang-orang dengan berbagai hal kepentingan.

Melihat hal itu, bangsa Eropa mulai melirik Indonesia sebagai tujuan perdagangannya. Dengan kata lain, Indonesia dipandang sangat potensial untuk dijadikan sebagai tempat memproduksi bahan-bahan kebutuhan pasar Eropa, sampai membuat kongsi dagang Eropa dengan nama (Vereenig-de Oost-Indische Compagnie) VOC pada Maret 1602. ${ }^{2}$ Tujuan utama VOC adalah untuk mencari rempah-rempah. Angkutan yang digunakan untuk mengangkut hasil produksi (rempah-rempah) dari daerah produksi menuju pasar adalah dengan menggunakan jalur sungai yang bisa menjangkau hingga daerah pedalaman. ${ }^{3}$ Penggunaan jalur sungai ini dinilai lebih efisien dan mobilisasi barang produksi bisa berjalan dengan lancar.

Namun, pada tahun 1808 eksistensi penggunaan angkutan jalur sungai sebagai jalur utama mobilisasi barang mulai mendapat persaingan dengan jalur lainnya, dikarenakan pada tahun tersebut mulai dibangun jalan Groote Postweg4 yang dipelopori oleh Daendels. Jalur tersebut menghubungkan antara Anyer sampai dengan Panarukan. Pembangunan jalan ini didasarkan pada kepentingan pertahanan dan kontrol wilayah di Jawa. ${ }^{5}$ Pembangunan jalan pos ini

2 M.C Rickflefs, Sejarah Indonesia Modern 1200-2008, (Terj) (Jakarta: PT. Serambi Ilmu Semesta, 2008), hlm 51.

3 Singgih Tri Sulistiyono, Perkembangan Pelabuhan Cirebon dan Pengaruhnya terhadap kehidupan sosial ekonomi masyarakat kota Cirebon 1859-1930, (Tesis) (Yogyakarta: Universitas Gadjah Mada, 1994), hlm 41.

${ }^{4}$ De Groote Postweg merupakan jalan raya penghubung di sepanjang pantai utara Jawa dari Anyer hingga Panarukan yang dibangun pada masa Gubernur Jenderal Herman Willem Daendels (1808-1811). Lihat Sartono Kartodirdjo, Pengantar Sejarah Indonesia Baru 15001900 dari Emporium sampai Imperium Jilid 1, (Jakarta: Gramedia, 1995), hlm 291.

${ }^{5}$ Endah Sri Hartatik, Dua Abad Jalan Raya Pantura, (Yogyakarta: Nurmahera. 2018), hlm 31. 360

Tamaddun: Jurnal Sejarah dan Kebudayaan Islam, Volume (8), Issue (2), Desember 2020 
memberikan warna baru dalam angkutan mobilitas barang, yakni waktu tempuh yang lebih singkat melalui jalur darat dengan menggunakan kendaraan angkutan seperti truk, mobil bak, dan lainlain.

Efek dari pembangunan jalur Groote Postweg adalah munculnya kota-kota baru yang saling terkoneksi satu dengan lainnya, ditambah lagi kebijakan Daendels dengan membagi Pulau Jawa menjadi 9 daerah prefectur. ${ }^{6}$ Daerah-daerah tersebut antara lain Tegal, Semarang, Pekalongan, Jepara, Rembang, Gresik, Surabaya, Pasuruan, dan Sumenep. Daerah-daerah tersebut pada umumnya memiliki pelabuhan sebagai titik vital bagi mobilitas barang dan manusia dengan dunia internasional.

Era baru dimulai ketika perdagangan liberal dihadirkan, dengan disahkannya Undang-Undang Agraria pada tahun 1870 yang dikenal dengan babak baru dalam periode kapitalisme modern yang diterapkan Pemerintah Kolonial Belanda terhadap tanah koloni mereka. ${ }^{7}$ Efek dari pengesahan Undang-Undang Agraria ini adalah pengusaha-pengusaha non pemerintahan (swasta) diberikan kebebasan untuk menanamkan modalnya di Hindia Belanda. Salah satu pengembangan pihak swasta di Hindia Belanda adalah mengelola industri gula dan tebu. ${ }^{8}$ Gula di sini berperan sebagai bahan produksi yang sangat laku keras di pasar Eropa, hingga

${ }^{6}$ Zainal Masduqi, Cirebon Dari Kota Tradisional Ke Kota Kolonial, (Cirebon: Nurjati Press, 2011), hlm 33.

${ }^{7}$ Endah Sri Hartatik, Op.Cit, hlm 97.

8 J Stroomberg, Hindia Belanda 1930, (Yogyakarta: IRCiSoD, 2018), hlm 185. 361

Tamaddun: Jurnal Sejarah dan Kebudayaan Islam, Volume (8), Issue (2), Desember 2020 
industri gula pasir di Jawa yang termasuk kekuasaan Hindia Belanda menjadi peringkat pertama produsen gula terbesar di dunia. ${ }^{9}$

Inovasi moda pengangkutan barang dan manusia yang efisien, cepat dan murah mulai dilirik oleh pihak swasta untuk menanamkan modalnya di Hindia Belanda. Inovasi tersebut melahirkan transportasi massal kereta api sebagai moda transportasi yang menjawab kondisi saat itu. Perusahan swasta yang pertama kali mendapat konsensi pembuatan jalur kereta api adalah NISM ${ }^{10}$ dengan rute Semarang-Yogyakarta tahun 1864-1873. ${ }^{11}$ Sementara di Cirebon, terdapat beberapa pabrik gula, antara lain, pabrik gula Sindang Laut, Karang Suwung, Gempol, Arjawinangun, dan Jatiwangi. Hal tersebut mendorong transportasi kereta api untuk dihadirkan dalam rangka pengangkutan dan mobilitas barang yang cepat dan efisien. Maka, pada 1897 diberikan konsesi kepada Semarang Cheribon Stroomtram Maatschappij (SCS) dengan rute Semarang Poncol sampai dengan Banjir Kanal (Stasiun Prujakan) dan Banjir Kanal (Prujakan) sampai dengan Kadipaten pada tahun 1901. ${ }^{12}$

Berangkat dari uraian tersebut, penulis ingin mengetahui secara lebih mendalam terkait perkeretaapian di Cirebon Barat beserta fungsi-fungsinya. Berpijak dengan terbatasnya sumber arsip yang dimiliki, tidak mematahkan penulis. Ditambah lagi posisi Cirebon

9 Ibid., hlm 185.

${ }^{10}$ Nederlandsch Indische Spoorweg Maatschaappij (NISM) adalah perusahaan kereta api swasta yang didirikan pada 27 Agustus 1863, yang menjadi perusahaan kereta api pertama di wilayah Hindia Belanda. Perusahaan NISM ini didirikan oleh W. Poolman, Alex Frazer, dan E.H Kol. Lihat Yoga, Prabowo, Diaz, Kereta Api Di Indonesia, (Yogyakarta: Jogja Bangkit Publisher, 2017), hlm 12.

${ }^{11}$ Imam Subarkah, Sekilas 125 Tahun Kereta Api Kita 1867-1992, (Bandung: Tidak Diterbitkan, 1992), hlm 9.

12 Ibid., hlm 16.

Tamaddun: Jurnal Sejarah dan Kebudayaan Islam, Volume (8), Issue (2), Desember 2020 
sebagai Kota Praja pada tahun 1906 semakin menambah penasaran penulis terkait perkeretaapian dan juga kota Cirebon.

\section{PEMBAHASAN}

Studi mengenai sejarah perkeretaapian di Cirebon, tidak lepas dari pengaruh kolonialisme orang-orang Eropa di Indonesia. Diawali dengan berlayarnya orang-orang Portugis yang mahir tentang ilmu pengetahuan geografi dan astronomi yang dapat mengantarkan mereka ke pantai barat Afrika. Tujuan utamanya adalah untuk mendapatkan kekayaan. Salah satu kekayaan tersebut adalah rempahrempah. ${ }^{13}$

Pada tahun 1595 di bawah komando Cornelis de Houtman ekspansi Belanda mulai menjajaki daerah penghasil rempah-rempah untuk berdagang, tepatnya berhasil mendarat di Banten. Kemudian pada pada 1602 Belanda membuat sebuah wadah kongsi dagang yang bernama Vereenigde Oost Idische Compagnie (VOC).

Eksistensi kongsi dagang VOC hanya berlangsung sampai dengan tahun 1799. Memasuki tahun 1830, VOC dinyatakan bangkrut dan digantikan Hindia Belanda. Pada masa ini telah ditetapkan sistem tanam paksa oleh Gubernur Jenderal Van Den Bosh yang mewajibkan setiap pribumi menanam tanaman paling laku keras di pasar Eropa, salah satunya adalah tebu. ${ }^{14}$ Dengan keberadaan tanam paksa tersebut, berimbas kepada banyaknya hasil produksi yang diperoleh. Terbukti wilayah pulau Jawa bagian barat hingga timur menjadi daerah penghasil tebu terbaik. Ditambah lagi dengan

\footnotetext{
${ }^{13}$ M.C Rickflefs, Op. Cit., hlm 41

${ }^{14}$ J. Stromberg, Op.Cit., hlm. 185.
} 
disahkannya Undang-Undang Agraria pada tahun 1870, menjadi pembuka jalan bagi pengusaha swasta untuk melakukan eksplorasi lebih jauh. ${ }^{15}$

Melihat kesempatan ini, Poolman, Frazer dan $\mathrm{Kol}^{16}$ sebagai peneliti dan ahli dari Nederlandsch Indische Spoorwer Maatschappij (NISM) memberi masukan kepada pemerintah Hindia Belanda untuk membangun jalur rel kereta pertama di Indonesia. Usulan tersebut akhirnya diterima oleh pemerintah Hindia Belanda dan memberikan konsensi pembangunan kepada $\mathrm{NISM}^{17}$, yang didasarkan kepada keputusan pemerintah Hindia Belanda tanggal 28 Agustus 1862 No. 1.18

Sejalan dengan itu, wilayah karesidenan Cirebon juga tak luput dari jangkauan lalu lintas kereta api. Dimulai dengan adanya konsensi pada akhir abad ke-19, tepatnya tahun 1897, oleh Semarang Cheribon Stoomtram Maatschappij (SCS) ${ }^{19}$ dengan rute stasiun Padrikan Semarang barat mengarah ke barat menuju Pekalongan, Tegal, dan

${ }^{15}$ Endah Sri Hartatik, Op.Cit., hlm 97.

16 W. Poolman, Alex Frazer, dan E.H Kol adalah seorang pendiri dari Perusahaan kereta Nederlandsch Indische Spoorweg Maatschappij (NISM). Rekam jejaknya sangat besar di dunia kereta api di Indonesia. Pada tahun 1864 mereka juga mendapatkan proyek untuk membangun jalur kereta api dari Batavia (Jakarta) sampai dengan Buitenzorg (Bogor). Lihat Yoga dkk, Kereta Api Di Indonesia, (Yogakarta: Jogja Bangkit Publisher, 2017), hlm. 12.

${ }^{17}$ Nederlandsch Indische Spoorweg Maatschappij (NISM) adalah perusahaan kereta api swasta yang didirikan pada 27 Agustus 1863, dan menjadi perusahaan kereta api pertama di wilayah Hindia Belanda. NISM didirikan setelah menerima konsesi dari pemerintah Hindia Belanda untuk membangun jalur kereta api pertama. Jalur ini menghubungkan Semarang dan Yogyakarta melalui Kedung Jati dan Solo, termasuk jalur cabang dari Kedung Jati Menuju Ambarawa untuk mendukung kepentingan Militer Hindia Belanda.

${ }^{18}$ Imam Subarkah, Op.Cit., hlm 7.

19 Semarang Cheribon Stoomtram Maatschappij (SCS) merupakan sauatu badan usaha yang menguasai lahan eksploitasi pada bidang transportasi yang terbentang di sebagian pantai utara. Berdasarkan Statuen yang dimuat dalam Staatscourant pada 25 Mei 1895. Lihat Djoko Marihandono, Dari konsesi ke Nasionalisasi Sejarah Kereta Api Cirebon-Semarang, (Jakarta: Direktorat Aset Tanah dan Bangunan PT. Kereta Api Indonesia), hIm 61.

Tamaddun: Jurnal Sejarah dan Kebudayaan Islam, Volume (8), Issue (2), Desember 2020 
Brebes. ${ }^{20}$ Kemudian memasuki Cirebon melewati daerah Losari, Bedilan, Gubang Gunung, Ciledug Centeng, Ciledug, Jatiseeng, Luwunggajah, Waled, Pabuaran, Cibogo, Jatipiring, Karangsuwung, Sigong, Sindanglaut, Kanci, Waruduwur, dan berakhir di Banjir Kanaal (Prujakan). ${ }^{21}$ Sesuai dengan Surat Keputusan Residen Cirebon nomor 1 tanggal 31 Maret 1900.22

Setelah membuka jalur Kereta Api Semarang-Cirebon, Semarang Cheribon Stoomtram Masstshappij (SCS) kemudian melanjutkan pembangunannya ke arah barat Cirebon sampai ke Kadipaten. Alasan utama dibangunya jalur ini adalah upaya pemenuhan kebutuhan transportasi untuk akomodasi pabrik-pabrik gula di Cirebon Barat, maupun lalu lintas penumpang di Cirebon Barat. Jalur ini dibangun dan resmi dioperasikan pada tahun 1901. Jalur ini membentang dari stasiun Prujakan menuju Kadipaten sepanjang $48 \mathrm{KM}$. Jalur ini mempunyai satu jalur percabangan, yakni percabangan Jamblang (Klangenan)-Gunung Giwur (Palimanan) sepanjang 5 KM yang dibuka pada tanggal 1 Juli 1922.23

${ }^{20}$ Officieele Reisgids der Spoor- en Tramwegen en Aan-Sluitende Automobieldiesten op Java en Madoera Uitgave van 1 Mei 1926, hlm. 42.

${ }^{21}$ Aditya, Gurnito, Dkk, Susur Jejak Kereta Api Cirebon-An. Makalah, (Bandung: Pusat Data, Informasi, dan Kepustakaan Kereta Anak Bangsa, 2016), hlm 13.

22 Miftahul Falah, Sejarah Sosial Ekonomi Majalengka Pada Masa Pemerintahan Hindia Belanda 1819-1942, (Dimuat dalam Jurnal Patanjala, Volume 3 Nomor 2, Juni 2011)., hlm205.

23 Iwan Hermawan, Kereta Api dan Tata Ruang Kota Cirebon Jawa Barat, (Bandung: Balai Arkeologi Jawa Barat, 2019), hlm 36.

Tamaddun: Jurnal Sejarah dan Kebudayaan Islam, Volume (8), Issue (2), Desember 2020 
Adapun jalur Semarang Cheribon Stoomtram Masstshappij (SCS) Cirebon-Kadipaten ini memiliki tempat pemberhentian kereta api, antara lain: ${ }^{24}$

1. Cheribon SCS.

2. Cheribon SS

3. Tengah Tani

4. Pesalaran (Plered).

5. Ploembon.

6. Djamblang.

7. Djamblang Kampung China.

8. Klangenan.

9. Palimanan.

10. Kedoengboender.
11. Tjiwaringin.

12. Parapatan.

13. Bongas.

14. Palasah.

15. Tjiborelang.

16. Djatiwangi.

17. Batoeroejoek.

18. Tjideres.

19. Kadipaten.

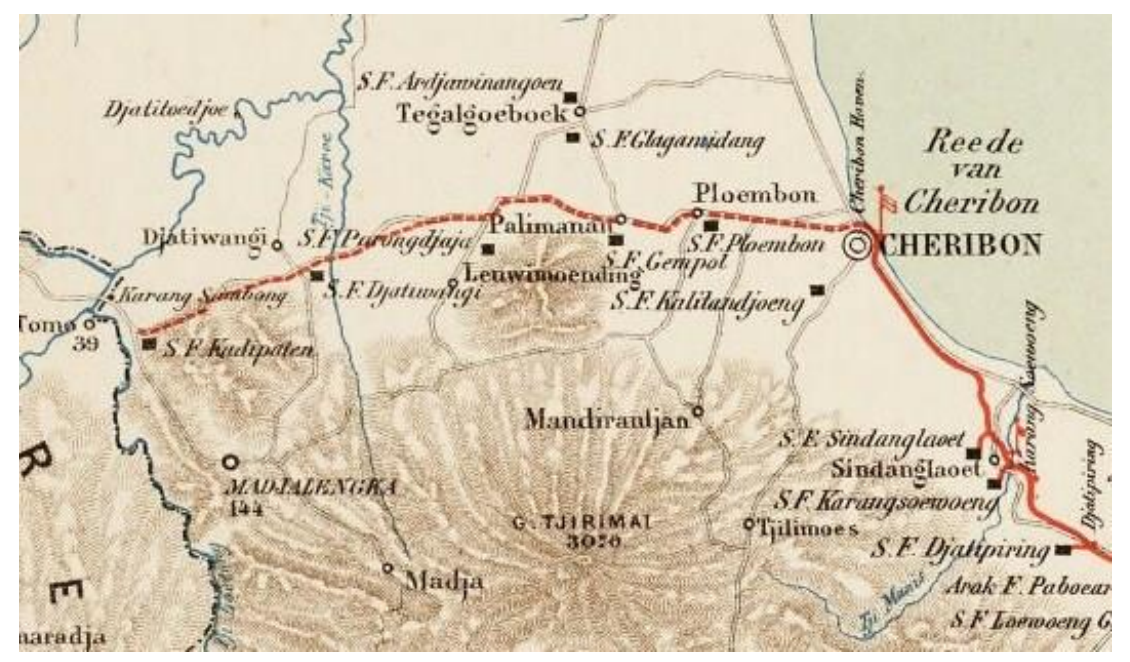

Peta 1. Peta Semarang Cheribon Stoomtram Maatschappij (SCS) tahun 1901

${ }^{24}$ Officiile Reisgids Der Spoor En Tramwegen En Aan Sluitende Automobieldisensten Op Java Madoera Uitgave van 1 Mei 1926 Boekhandel En drukkerijen N.V. Sie Dhian Ho Solo, hlm. 32.

Tamaddun: Jurnal Sejarah dan Kebudayaan Islam, Volume (8), Issue (2), Desember 2020 
(Sumber: maps.leiden.edu)

Jalur selanjutnya yang terdapat dalam wilayah Cirebon Barat adalah jalur Cirebon-Cikampek. Jalur ini diberikan konsensi oleh Statsspoorwegen (SS). Statsspoorwegen (SS) merupakan perusahaan dari pemerintah Hindia Belanda yang fokus di bagian transportasi Kereta Api Hindia Belanda. Jalur ini difungsikan oleh Hindia Belanda untuk menghubungkan kota-kota di pantai utara seperti Cirebon, dan Semarang untuk bisa terhubung dengan Batavia. Jalur CikampekCirebon ini diresmikan pada 1912 oleh Gubernur Jenderal A.W.F. Idenburg. ${ }^{25}$

Pembukaan jalur ini memiliki banyak alasan. Terlebih dengan posisi geografis Cikampek yang terletak di pesisir utara Jawa. Juga Cirebon dan Semarang terletak di pesisir utara Jawa. Dengan kata lain, pembukaan jalur transportasi Kereta Api Cikampek-Cirebon ini merupakan efisiensi dari penggunaan transportasi lama, dimana tranportasi lama yang menghubungkan Cikampek, Cirebon, dan Semarang menggunakan moda transportasi laut.

Adapun Stasiun awal pendirian jalur Kereta Api CikampekCirebon sebagai berikut:

1. Stasiun Cirebon $(\mathrm{CN})$

2. Halte Cangkring (CNK)

3. Halte Bangodua (BDW)

4. Halte Arjawinangun (AWN)

5. Halte Tegalgubug (TLG)

6. Halte Kaliwedi (KLW)

${ }^{25}$ Zainal Masduqi, Op.Cit., hlm. 70.

Tamaddun: Jurnal Sejarah dan Kebudayaan Islam, Volume (8), Issue (2), Desember 2020 
7. Halte Purwantara (PRT)

8. Halte Kertasemaya (KTM)

9. Halte Jatibarang (JTB)

10. Halte Tegalsari (TLS)

11. Halte Terisi (TIS)

12. Halte Kadokangabus (KAB)

13. Halte Sukamelang (SUK)

14. Halte Cilegeh (CLH)

15. Halte Cipedang (CPA)

16. Halte Haurgeulis (HGL)

17. Halte Cipunegara (CRA)

18. Halte Cipicung (CPC)

19. Halte Cikaum (CKM)

20. Halte Pegaden Baru (PGB)

21. Halte Gambarsari (GBR)

22. Halte Cikaum (CKM)

23. Halte Pasirbungur (PAS)

24. Halte Pringkasap (PRI)

25. Halte Pabuaran (PAB)

26. Halte Tanjungrasa (TJS)

27. Halte Pangulah Simpang (PLS)

28. Stasiun Cikampek (CKP) 


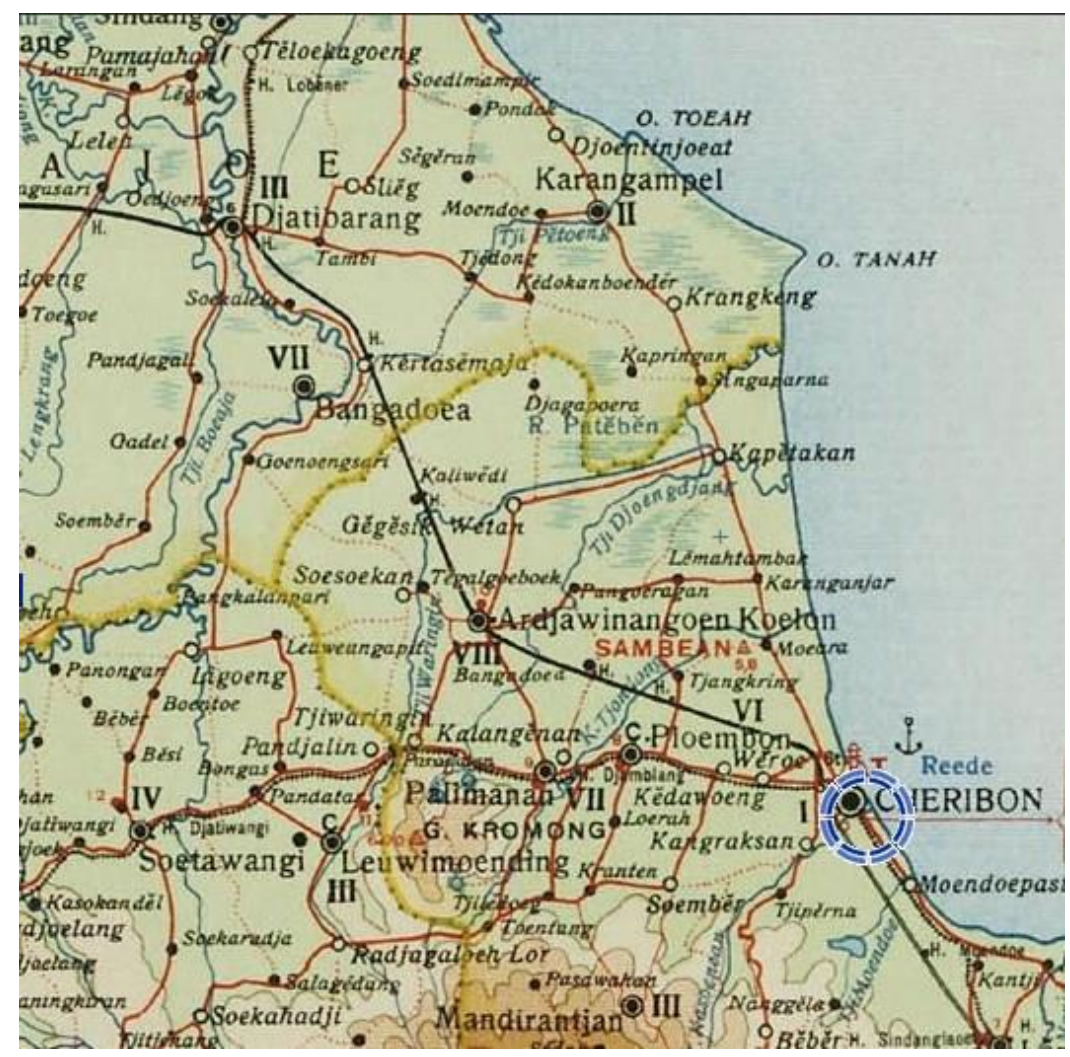

Peta 2. Peta Tematik tahun 1912 yang menampilkan jalur Statsspoorwegen (SS) (Sumber : maps.leiden.edu)

Dengan berkembangnya moda transportasi jalur kereta api di Cirebon Barat mengakibatkan sektor perekonomian mulai memberikan dampak yang signifikan bagi ekonomi kolonial Hindia Belanda. Dengan disahkannya Undang-Undang Agraria pada tahun 1870 oleh pemerintah kolonial Hindia Belanda membuat investor asing banyak yang masuk ke Hindia Belanda, tujuan dari pada itu adalah tujuan ekonomi kolonial. Salah satu usaha pemerintah kolonial Hindia Belanda adalah dengan pembukaan lahan pertanian, dan

Tamaddun: Jurnal Sejarah dan Kebudayaan Islam, Volume (8), Issue (2), Desember 2020 
perkebunan. ${ }^{26}$ Berikut ini adalah beberapa peran ekonomi dari fungsi jalur-jalur baru kereta api di Cirebon Barat adalah sebagai berikut:

1. Jalur Angkutan Gula

Setidaknya pada pertengahan abad 19, eksistensi institusi ini menjadi objek perdebatan yang konvensional khususnya di kalangan para pembuat kebijakan kolonial baik di Belanda maupun di Hindia Belanda, di bawah sistem Cultuurstelsel. Pada masa Cultuurstelsel, terdapat sistem kerja yang dikenal sebagai kontrak gula (Suikercontrach). Dalam kontrak ini, pemerintah wajib memerintahkan penduduk untuk menanam tebu sebagai bagian dari aturan tanam wajib dan menyetorkannya ke gudang-gudang negara atau diambil langsung oleh pengusaha pabrik gula untuk digiling menjadi komoditas gula. Hasil penggilingannya wajib dijual kepada pemerintah dengan harga yang telah ditetapkan sebelumnya. Pada saat bersamaan pabrik gula menghadapi sisi yang dualistis. Pada satu sisi pemerintah tidak memberikan peluang kepada peranan swasta untuk terlibat dalam proses produksi agraria di Jawa, dan menjadikan tanah koloni murni sebagai lahan eksploitasi negara, disisi yang lain, pemerintah memerlukan pabrik-pabrik gula untuk mengolah dari bahan mentah menjadi barang jadi, yaitu dari tebu menjadi gula. ${ }^{27}$

Berikut ini merupakan tabel persebaran pabrik gula di sepanjang jalur Samarang Cheribon Stoomtram Maatschappij (SCS) yang terbentang dari Semarang hingga Kadipaten.

\footnotetext{
${ }^{26}$ Miftahul Falah, Op.Cit., hlm. 95.

27 Ibid., hlm. 95.
} 
Tabel 2. Daftar Pabrik Gula yang dilalui Transportasi Kereta Api Samarang Cheribon Stoomtram Maatschappij (SCS) pada akhir abad XIX dan Awal Abad XX.

\begin{tabular}{|c|c|c|}
\hline No & Nama Pabrik Gula & $\begin{array}{l}\text { Wilayah Administratif } \\
\text { Karesidenan }\end{array}$ \\
\hline 1 & Besito & Semarang \\
\hline 2 & Kaliwungu & Semarang \\
\hline 3 & Pakis & Semarang \\
\hline 4 & Cepiring & Semarang \\
\hline 5 & Gemu & Semarang \\
\hline 6 & Langse & Semarang \\
\hline 7 & Rendeng & Semarang \\
\hline 8 & de Hoop (Mayong) & Semarang \\
\hline 9 & Trangkil & Semarang \\
\hline 10 & Banyuputih & Semarang \\
\hline 11 & Tanjung & Semarang \\
\hline 12 & Mojo & Semarang \\
\hline 13 & Adiwerma & Pekalongan \\
\hline 14 & Banjardawa & Pekalongan \\
\hline 15 & Kalimati & Pekalongan \\
\hline 16 & Patarukan & Pekalongan \\
\hline 17 & Balapurang & Pekalongan \\
\hline 18 & Banjaratma & Pekalongan \\
\hline 19 & Pagongan & Pekalongan \\
\hline 20 & Jati Barang & Pekalongan \\
\hline 21 & Dukuh Waringin & Pekalongan \\
\hline 22 & Pangkah & Pekalongan \\
\hline 23 & Kemanglen & Pekalongan \\
\hline 24 & Kemantren & Pekalongan \\
\hline 25 & Sragi & Pekalongan \\
\hline 26 & $\begin{array}{l}\text { Comal (Wonopringgo } \\
\text { dan Tirto) }\end{array}$ & Pekalongan \\
\hline 27 & Sumberharjo & Pekalongan \\
\hline 28 & Ketanggungan Barat & Pekalongan \\
\hline
\end{tabular}




\begin{tabular}{|l|l|l|}
\hline 29 & Niew Losari & Cirebon \\
\hline 30 & Niew Tersana & Cirebon \\
\hline 31 & Karang Suwung & Cirebon \\
\hline 32 & Jati Piring & Cirebon \\
\hline 33 & Luwung Gajah & Cirebon \\
\hline 34 & Sindang laut & Cirebon \\
\hline 35 & Surawinangun & Cirebon \\
\hline 36 & Arjawinangun & Cirebon \\
\hline 37 & Gempol & Cirebon \\
\hline 38 & Parung Jaya & Cirebon \\
\hline 39 & Jatiwangi & Cirebon \\
\hline 40 & Kadipaten & Cirebon \\
\hline
\end{tabular}

(Sumber : Endah Sri Hartatik, 2018)

2. Jasa Angkutan Selain Gula

Selain berfungsi sebagai transportasi pengangkut gula dan tebu, fungsi dari jalur kereta api di Cirebon barat khususnya Semarang Cheribon Stoomtram Masstshappij (SCS) dan Statsspoorwegen (SS) berfungsi juga sebagai transportasi pengangkut selain gula. Cirebon sejak dulu sudah dikenal sebagai daerah potensial penghasil berbagai macam sumber daya alam, salah satunya adalah kopi, padi, sayuran, indigo, dan lain-lain. ${ }^{28}$ Pada pembahasan sub bab ini penulis tidak mengangkat tentang potensi kopi di wilayah Cirebon Barat, karena kopi merupakan produk Cultuurstelses kolonial Belanda. Namun pada perkembangan selanjutnya setelah jalur

${ }^{28}$ Faisal Arif, Perubahan Eksistensi Sungai Dan Pengaruhnya Bagi Kehidupan Sosial Ekonomi Masyarakat Kota Cirebon Pada Masa Hindia Belanda Tahun 1900-1942, Skripsi: (Cirebon: Jurusan Sejarah Peradaban Islam IAIN Syekh Nurjati Cirebon, 2019), hlm 66. 
Semarang Cheribon Stoomtram Masstshappij (SCS) dibuka, fungsi utamanya adalah mengangkut bahan baku dan hasil produksi di wilayah Cirebon-Kadipaten.

Selain fungsi pengangkutan tersebut, Semarang Cheribon Stoomtram Masstshappij (SCS) juga berfungsi sebagai wadah perdagangan dengan menggunakan kereta api sebagi transportasinya. Terbukti dengan difasilitasinya pabrik arak dan spirtus di wilayah Palimanan pada tahun 1928. Nilai ekspornya berjumlah $f$. 1.755.585. ${ }^{29}$ Dengan terkoneksinya jalur kereta antara pabrik arak dan spirtus Palimanan dengan Semarang Cheribon Stoomtram Masstshappij (SCS) membuat akses jangkauan pabrik arak dan spirtus Palimanan ini berhasil masuk pasar internasional dengan tujuan negara-negara Eropa. Selain pabrik arak dan spirtus Palimanan yang mendapat akses jangkauan dari Semarang Cheribon Stoomtram Masstshappij (SCS), pabrik batu di kawasan Gunung Giwur pun mendapat jangakauan khusus dari Semarang Cheribon Stoomtram Masstshappij (SCS) dengan membangun ruas percabangan dari Jamblang (Klangenan) menuju ke Gunung Giwur sepanjang 5 KM. Jalur ini dibuka pada tahun 1922.30 Jalur tersebut merupakan percabangan Gunung Giwur yang diperuntukkan untuk angkutan batu Ballast. ${ }^{31}$

29 Tim Penulis Arsip Nasional Republik Indonesia, Memori Serah Jabatan 1921-1930 (Jawa Barat), (Jakarta: Arsip Nasional Republik Indonesia, 1977) hlm. CLI.

${ }^{30}$ Aditya, Gurnito, Dkk, Op.Cit., hlm 29.

${ }^{31}$ Ballast atau disebut juga sebagai batu yang digunakan untuk media bantalan rel trem ataupun rel kereta api yang mempunyai fungsi sebagai bantalan antara baja rel dengan tanah secara langsung. Pada daerah Gunung Giwur ini diperoleh dari komplek pegunungan batu

Tamaddun: Jurnal Sejarah dan Kebudayaan Islam, Volume (8), Issue (2), Desember 2020 
Maskapai Statsspoorwegen (SS) di wilayah Cirebon Barat juga tak kalah dengan Semarang Cheribon Stoomtram Masstshappij (SCS). Perusahaan milik pemerintah kolonial Belanda ini mendapat konsesi pembangunan jalur kereta api Cikampek-Cirebon pada tahun 1912.32 Dalam hal peran ekonomi, jalur Cikampek-Cirebon ini melayani berbagai kebutuhan. Pada umumnya lalu lintas kereta api erat kaitannya dengan jalur gula, namun salah satu fungsi dari jalur ini adalah jasa angkutan selain gula.

Menurut laporan dari Dinas Perjalanan kereta api, wilayah Statsspoorwegen (SS) pada tahun 1929 di Cirebon Barat meliputi halte Kaliwedi, Arjawinangun, Bangoduwa lebih difungsikan sebagai stasiun pengiriman dari pada stasiun penerima. Halte Arjawinangun menjadi stasiun pengiriman beras dengan besaran (1.170 Ton), sayuran dengan besaran (740 Ton), buahbuahan dengan besaran (325 Ton), kentang (254 Ton) dan kacang tanah dengan besaran (160 Ton). Semuanya dikirim ke luar karesidenan Cirebon. Halte Kaliwedi menjadi stasiun pengiriman sayuran dan buah-buahan. Halte Cangkring (Distrik Plumbon) menjadi stasiun penerima beras dari Indramayu, tepung gaplek dari Bandung dan halte Manggarai.

disekitaran Gunung Giwur. Lihat. Iwan Hermawan, Laporan Penelitian arkeologi Kereta Api dan Tata Ruang Kota Cirebon Jawa Barat (Bandung: Balai Arkeologi Jawa Barat, 2019), hlm 3. Di daerah Jawa Tengah khususnya di wilayah Semarang, Ballast ini diperoleh dari batuan sungai yang diangkut oleh para buruh. Lihat., Endah Sri Hartatik, Agustinus Supriyono, DKK, Transportasi Jalan Raya Menggantikan Kereta Api Di Pantai Utara Jawa Tengah Awal Abad XX Sampai Orde Baru, Laporan Akhir Hibah Strategis Nasional. (Semarang: Fakultas IImu Budaya Universitas Diponegoro, 2008), hlm 18.

32 Imam Subarkah, Op.Cit., hlm 16.

Tamaddun: Jurnal Sejarah dan Kebudayaan Islam, Volume (8), Issue (2), Desember 2020 
Dari halte Cangkring ini dikirim buah-buahan, terutama mangga dengan besaran (1.107 Ton) dan kacang tanah ke kotakota di sebelah barat yang terletak di sepanjang jalur kereta api Cirebon-Cikampek. ${ }^{33}$

Selain memberikan peran ekonomi terhadap wilayah Cirebon Barat, dengan adanya jalur kereta Semarang Cheribon Stoomtram Masstshappij (SCS) dan Statsspoorwegen (SS) ini, membuat tatanan sosial masyarakat Cirebon Barat mengalami dinamika perubahan. Selain itu, dengan adanya jalur kereta api yang menembus wilayah Cirebon Barat ini mempunyai peran tersendiri terhadap daerah Cirebon Barat (Local Zone), serta juga berperan di daerah luar wilayah Cirebon Barat (Java Zone). Adapun peran sosial dengan adanya jalurjalur baru tersebut antara lain:

\section{Lokal Zone}

Ketika pembukaan pabrik-pabrik gula semakin gencar dilakukan seiring berkembangnya moda transportasi kereta api, tentunya memberikan warna tersendiri pada wilayah yang dibangun pabrik-pabrik tersebut. Khususnya wilayah Cirebon Barat ini sangatlah memberikan warna tersendiri. Salah satunya adalah meningkatnya jumlah buruh pabrik-pabrik gula, seiring dengan pembangunan pabrik-pabrik gula di wilayah Cirebon Barat.

Buruh, merupakan salah satu penopang penting dalam kegiatan produksi pabrik-pabrik gula khusunya di Cirebon Barat. Buruh dalam perusahaan perkebunan atau pabrik gula, biasanya di bawah

33 Tim Penulis Arsip Nasional Republik Indonesia, Memori Serah Jabatan 1921-1930 (Jawa Barat), (Jakarta: Arsip Nasional Republik Indonesia, 1977), hlm. CLII. 
pengawasan tuan kebon. ${ }^{34}$ Tuan kebon ini biasanya membawahi buruh laki-laki dan perempuan di perkebunan investor asing.

Dengan bekerjanya buruh-buruh lokal pribumi di pabrik gula wilayah Cirebon Barat, membuat para pekerja ini mengenal sistem upah. ${ }^{35}$ Sistem upah ini biasanya diberikan setiap hari oleh para pemilik pabrik gula. Namun pemberian upah tersebut disertai dengan tanggung jawab masing-masing buruh biasanya bekerja selama 12 jam dalam sehari, dan hari libur yang ditetapkan tidak selalu teratur, hanya satu hari per dua minggu saja untuk libur. ${ }^{36}$

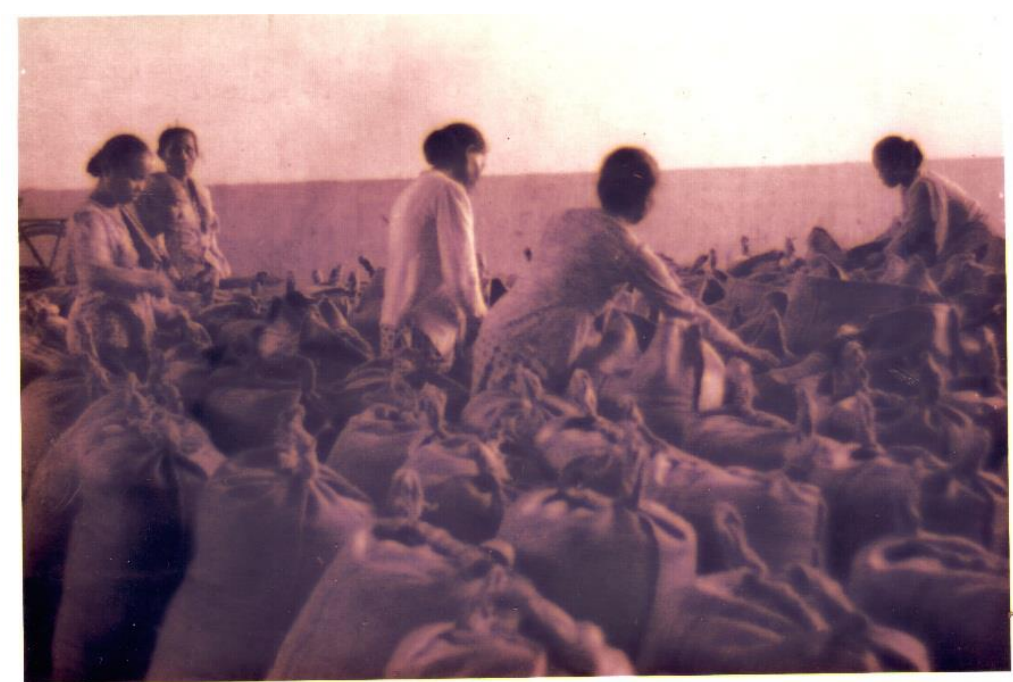

Gambar 1. Pekerja Pekerja wanita Pabrik Gula Gempol (Sumber : ANRI, Kempen Jawa Barat No. 674.)

Selain memberikan warna tersendiri bagi masyarakat Cirebon Barat, dengan adanya jalur kereta ini juga lalu lintas Local di Cirebon Barat menjadi semakin mudah. Seperti terkoneksinya pusat-pusat industri

${ }^{34}$ Jan Breman, Menjinakkan Sang Kuli, (Jakarta: Pustaka Utama Graviti, 1997), hlm 81.

35 Ibid., hlm 116.

${ }^{36}$ John Ingleson, Perkotaan, Masalah Sosial \& Perburuan Di Jawa Masa Kolonial, (Depok: Komunitas Bambu, 2013), hlm 42. 
di Cirebon Barat dengan pelabuhan semakin membuat perekonomian kolonial di Hindia Belanda khususnya Karesidenan Cirebon menjadi sangat baik, dan kolonial Belanda mendapat keuntungan yang sangat besar dalam sektor perekonomian kolonial ini.

\section{Java Zone}

Java Zone atau pun bisa disebut juga sebagai daerah Jawa. Maksud dari penulis adalah dengan adanya jalur-jalur baru, khususnya jalur Cirebon-Kadipaten milik Semarang Cheribon Stoomtram Masstshappij (SCS) serta jalur Cikampek-Cirebon milik Statsspoorwegen (SS) mampu memberikan peran yang sangat besar bagi wilayah kolonial Hindia Belanda khususnya di daerah Jawa. Dengan terhubungnya rangkaian jalur kereta ini dengan kota-kota besar yang memiliki pelabuhan, membuat akses mobilitas kolonial Hindia Belanda semakin menjadi jadi. Pusat pemerintahan di Batavia dapat terkoneksi sampai ke Surabaya melalui jalur kereta api ini.

Berikut ini adalah foto jaringan kereta api pada tahun 1926 di Jawa-Madura:

Tamaddun: Jurnal Sejarah dan Kebudayaan Islam, Volume (8), Issue (2), Desember 2020 


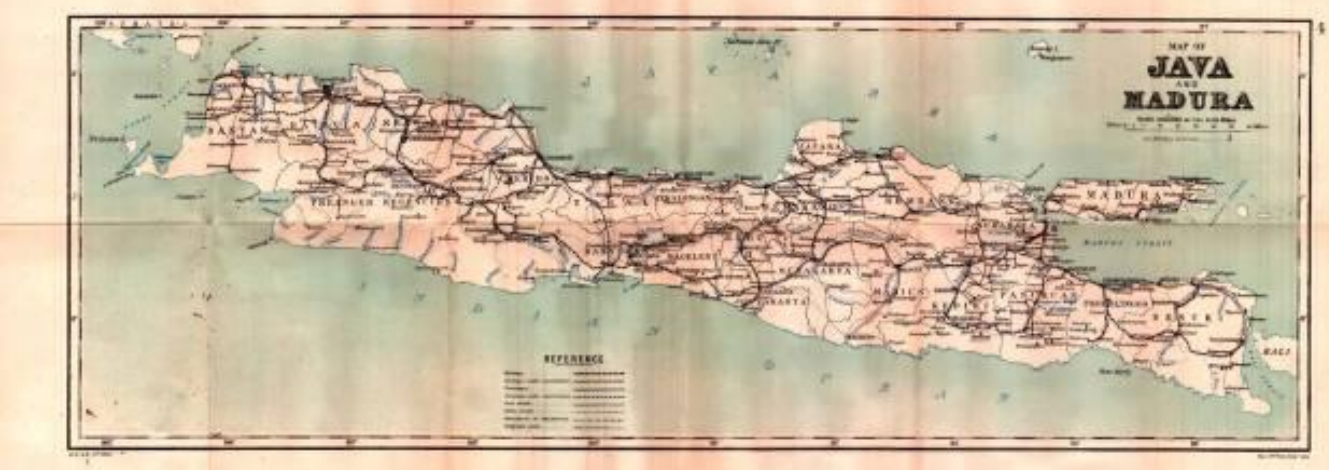

Peta 3. Peta Jaringan Kereta Api Tahun 1930-an.

(Sumber : Officieele Reisgids der Spoor en Tramwegen en aan Sluitende Automobieldiensten op Java en Madoera, 1926.)

Dalam peta, terlihat dominasi perusahaan pemerintah Kolonial Belanda dalam memegang konsesi jalur kereta api di Jawa pada khususnya. Tanda atau indeks yang menunjukan jalur konsesi di bawah naungan Statsspoorwegen (SS) adalah garis yang menghubungkan sebuah daerah ditandai dengan garis yang tidak terputus. Berbeda halnya dengan perusahaan kereta api swasta pemegang jalur konsesi dalam peta di atas. Pemegang jalur konsesi kereta api swasta ditandai dengan garis putus-putus yang menghubungkan sebuah daerah, contohnya adalah jalur CirebonKadipaten.

Adapun peran dari masing-masing Semarang Cheribon Stoomtram Masstshappij (SCS) sebagai pemegang konsesi jalur Cirebon-Kadipaten dan Statsspoorwegen (SS) sebagai pemegang

Tamaddun: Jurnal Sejarah dan Kebudayaan Islam, Volume (8), Issue (2), Desember 2020 
konsesi jalur Cikampek-Cirebon dengan peran Java Zonenya antara lain:

\section{a. Semarang Cheribon Stoomtram Masstshappij}

Semarang Cheribon Stoomtram Masstshappij (SCS) memiliki konsesi jalur kereta api yang membentang dari Karesidenan Semarang sampai dengan Karesidenan Cirebon. Jalur ini lebih dikenal dengan Suikerlijn atau jalur gula. Perusahaan SCS ini mengakomodir lalu lintas gula di sepanjang jalurnya. Khususnya di Cirebon mengakomodir sekitar 8 Pabrik Gula. Pabrik gula tersebut antara lain 3 (Tersana baru, Leuweunggajah dan Surawinangun-Plumbon) milik Nederlandsche Handelmaatschappij, 2 (Gempol dan Arjawinangun) milik Aments, 1 milik Maatschappij tot Exploitatie van de Suikerfabriek Sindanglaut, 1 milik Maatschappij tot Exploitatie van de Suikerondernemingen Karangsuwung, dan 1 Jatipiring, milik keluarga Cina Kwee. ${ }^{37}$ Selain itu pihak SCS juga mengakomodir hasil pertanian pribumi di wilayah Karesidenan Cirebon. Terbukti dengan stasiun Losari di Cirebon Timur yang dikenal sebagai daerah penghasil bawang merah dengah kualitas yang baik. Bawang-bawang ini nantinya akan di distribusikan menuju Cirebon, selanjutnya ke Jawa Tengah, dan Batavia. ${ }^{38}$ Dengan kata lain, lalu lintas hasil eksploitasi kolonial Belanda di wilayah Hindia Belanda menjadi lancar berkat dari jaringan kereta api yang sudah tersambung dengan kota-kota besar di Jawa.

\section{b. Statsspoorwegen}

${ }^{37}$ Tim Penulis Arsip Nasional Republik Indonesia, Op.Cit., hlm. CLIII.

38 Ibid., hlm. CLI. 
Statsspoorwegen (SS) sebuah perusahaan milik kolonial Hindia Belanda yang mengelola transportasi kereta api. Salah satu jalur yang dimilikinya adalah jalur Cikampek Cirebon. ${ }^{39}$ Peran jalur ini terhadap lalu lintas daerah Jawa adalah memberikan akomodasi transportasi bagi tiap-tiap sektor vital kolonial Belanda, seperti pemerintahan, industri, dan pelabuhan.

Dalam segi kepemerintahan, Statsspoorwegen (SS) memiliki peran dalam koordinasi pemerintah pusat di Batavia dengan pemerintah Residen guna memperlancar eksploitasi kolonial Belanda. Salah satu contohnya adalah proyek perbaikan jembatan Statsspoorwegen di wilayah Karesidenan Cirebon yang menelan biaya $f$. 34.210 .40 Dengan adanya koordinasi pemerintah pusat dengan pemerintah lokal tersebut semakin memperkokoh eksistensi kolonial Belanda dalam mengeksploitasi segala potensi di Hindia Belanda. Bukan hanya di Karesidenan Cirebon saja yang dapat terhubung dengan mudah dalam pemerintahan kolonial Belanda, tetapi juga daerah Karesidenan lainnya bisa dengan mudah terhubung dengan pemerintah pusat melalui jaringan transportasi kereta api yang kian menjamur.

Tabel 4. Kegiatan Ekspor Import barang-barang terpenting di Jawa dan Madura tahun 1929.

\begin{tabular}{|l|l|l|l|l|}
\hline \multirow{2}{*}{ Barang } & \multicolumn{4}{|l|}{ Pelabuhan } \\
\cline { 2 - 5 } & T. Priok & Cirebon & Semarang & Surabaya \\
\hline Ikan Kering & $f 7,737,760$ & $f 2,402,911$ & $f 903,122$ & $f 1,777,584$ \\
\hline Tembakau & $f 1,412,968$ & $f 8,149,801$ & $f 4,142,360$ & - \\
\hline
\end{tabular}

\footnotetext{
${ }^{39}$ Imam Subarkah, Op.Cit., hlm. 28.

${ }^{40}$ Uits Cheribon's Geschiedenis II Door Godee Molsbergen, hlm. 24.
} 
\begin{tabular}{|l|l|l|l|l|} 
Teh & $f 518,973$ & $f 5,595,226$ & $f 2,778,958$ & $f 383,908$ \\
\hline
\end{tabular}

(Sumber: Arsip Nasional Indonesia, 1976)

Dalam segi industri kolonial Belanda, Statsspoorwegen (SS) memiliki peran dalam akomodasi pengangkutan produk industri kolonial di Karesidenan Cirebon. Salah satu contohnya adalah pemberian akomodasi pengangkutan kepada industri rokok British American Tobacco (BAT). Barang industri yang telah diproduksi BAT ini selanjutnya akan dikirim menuju Pelabuhan dengan bantuan kereta api. Adapun Pelabuhan Cirebon mendapat rangking ke-2 pada tahun 1929 dalam hal ekspor dan impor barang-barang perdagangan terpenting di Jawa dan Madura dengan komoditas unggulannya berupa tembakau.

Tamaddun: Jurnal Sejarah dan Kebudayaan Islam, Volume (8), Issue (2), Desember 2020 


\section{DAFTAR PUSTAKA}

\section{Arsip}

Officieele Reisgids der Spoor en Tramwegen en aan Sluitende Automobieldiensten op Java en Madoera 1926.

Regeerings-Almanak voor Nederlands-Indie 1920 Eerste Gedeelte Grondgebied en Bevolking, Inrichting van het Bestuur van Nederlandsch-Indie en Bijlagen.

Uits Cheribon's Geschiedenis II Door Godee Molsbergen.

\section{Internet}

Falah Miftahul, Sejarah Sosial Ekonomi Majalengka Pada Masa Pemerintahan Hindia Belanda 1819-1942, (Dimuat dalam Jurnal Patanjala, Volume 3 Nomor 2, Juni 2011), diunduh pada 02 Mei 2020 Pukul 15.32 WIB.

\section{Buku}

Abdurrohman, Dudung. 1996. Metode Penulisan Sejarah. Surabaya: Logos Wacana Ilmu.

Aditya, Guritno, DKK. 2016. Susur Jejak Kereta Api Cirebon-An. Makalah, Bandung: Pusat Data, Informasi, dan Kepustakaan Kereta Anak Bangsa. 
Arif, Faisal. 2019. Perubahan Eksistensi Sungai Dan Pengaruhnya Bagi Kehidupan Sosial Ekonomi Masyarakat Kota Cirebon Pada Masa Hindia Belanda Tahun 1900-1942. Skripsi, Cirebon: Jurusan Sejarah Peradaban Islam IAIN Syekh Nurjati Cirebon.

Breman, Jan. 1997. Menjinakkan Sang Kuli. Jakarta: PT Pustaka Utama Grafiti.

Endah, Sri Hartatik, Agustinus Supriyono, DKK, 2009. Transportasi Jalan Raya Menggantikan Kereta Api Di Pantai Utara Jawa Tengah Awal Abad XX Sampai Orde Baru. Laporan Akhir Hibah Penelitian Strategis Nasional Tahun 2009, Semarang: Fakultas Ilmu Budaya Universitas Dipenogoro.

Endah, Sri Hartatik. 2018. Dua Abad Jalan Raya Pantura. Yogyakarta: Nurmahera.

Hermawan, Iwan. 2019. Kereta Api dan Tata Ruang Kota Cirebon Jawa Barat. Laporan Penelitian Arkeologi. Bandung: Balai Arkeologi Jawa Barat,

Indonesia, Tim Penulis Arsip Nasional Republik. 1977. Memori Serah Jabatan 1921-1930 (Jawa Barat). Jakarta: Arsip Naional Republik Indonesia.

Ingleson, John. 2013. Perkotaan, Masalah Sosial, \& Perburuhan di Jawa Masa Kolonial. Depok: Komunitas Bambu.

Masduqi, Zaenal. 2011. Cirebon Dari Kota Tradisional ke Kota Kolonial. Cirebon: Nurjati Press.

Rachmat, Saefur. 2009. Ilmu Sejarah Dalam Perspektif Ilmu Sosial.Yogyakarta: Graha Ilmu. 
Ricklefs, M.C. Sejarah Indonesia Modern 1200-2008. Jakarta: PT Serambi Ilmu Semesta.

Sanusi, Anwar. 2013. Pengantar Ilmu Sejarah. Cirebon: Syekh Nurjati Press.

Sjamsuddin, Helius. 2007. Metodologi Sejarah. Yogyakarta: Penerbit Ombak.

Stoomberg, J. 2018. Hindia Belanda 1930. Yogyakarta: IRCiSoD.

Subarkah, Imam. 1992. Sekilas 125 Tahun Kereta Api Kita 1867-1992. Bandung: Karya tidak diterbitkan.

Sulistiono, Singgih Tri. 1998. Perkembangan Pelabuhan Cirebon Dan Pengaruhnya Terhadap Kehidupan Sosial Ekonomi Masyarakat Cirebon 1859-1930. Tesis. Yogyakarta: Universitas Gajah Mada.

Yoga, Prabowo, Diaz. 2017. Kereta Api Di Indonesia Sejarah Lokomotif Uap. Yogyakarta: Jogja Bangkit Publisher. 